\title{
YOU CAN'T GET THERE FROM HERE
}

\author{
The Past as Present in Small-Town
}

Ontario Fiction 
This page intentionally left blank 


\title{
You Can't Get There from Here
}

\section{The Past as Present in Small-Town \\ Ontario Fiction}

\author{
RYAN PORTER
}




\author{
(C) University of Toronto Press 2019 \\ Toronto Buffalo London \\ utorontopress.com \\ Printed in Canada
}

ISBN 978-1-4875-0424-3

(6)

Printed on acid-free, $100 \%$ post-consumer recycled paper with vegetable-based inks.

\title{
Library and Archives Canada Cataloguing in Publication
}

Porter, Ryan, 1978-, author

You can't get there from here : the past as present in small-town

Ontario fiction / Ryan Porter.

Includes bibliographical references and index.

ISBN 978-1-4875-0424-3 (hardcover)

1. Canadian fiction (English) - 20th century - History and criticism.

2. Canadian fiction (English) - 21st century - History and criticism.

3. Small cities - In literature. 4. Ontario - In literature. I. Title.

II. Title: You cannot get there from here.

University of Toronto Press acknowledges the financial assistance to its publishing program of the Canada Council for the Arts and the Ontario Arts Council, an agency of the Government of Ontario.

Canada Council for the Arts
Conseil des Arts du Canada
ONTARIO ARTS COUNCIL CONSEIL DES ARTS DE L'ONTARIO

an Ontario government agency un organisme du gouvernement de l'Ontario 
For Kareen, Georgia, and Rosie 
This page intentionally left blank 